\title{
Effect of $\mathrm{TiO}_{2}$ Nanotube Layers Thickness on Periodontal Ligament Cells
}

Ling $\mathrm{Xu}, \mathrm{Kai}$-ge Lv and Wei-qiang $\mathrm{Yu}^{*}$

Department of Prosthodontics, School of Stomatology, Ninth People's Hospital, School of Medicine, Shanghai JiaoTong University, Shanghai Research Institute of Stomatology, Shanghai 200011, China

"Corresponding author: Yu WQ, Department of Prosthodontics, School of Stomatology, Ninth People's Hospital, School of Medicine, Shanghai JiaoTong University. Shanghai, China, Tel: +86 2123271699 (5691); Fax: +86 2163136856 ; E-mail: ywqhuai@126.com

Rec date: Mar 21, 2016; Acc date: Apr 04, 2016; Pub date: Apr 11, 2016

Copyright: (C) $2016 \mathrm{Xu} \mathrm{L}$, et al. This is an open-access article distributed under the terms of the Creative Commons Attribution License, which permits unrestricted use, distribution, and reproduction in any medium, provided the original author and source are credited.

\begin{abstract}
Periodontal ligament cells (PDLCs) remaining in the tooth-extraction socket are involved in osseointegration after immediate implantation; however, their interaction with different implant surfaces has not been investigated. The aim of this study was to compare PDLC growth on substrates composed of differently sized titanium dioxide $\left(\mathrm{TiO}_{2}\right)$ nanotubes with that on flat Ti. PDLC growth on Ti nanotubes was evaluated in terms of cell adhesion, proliferation, and osteogenic differentiation based on the expression of alkaline phosphatase (ALP), type 1 collage (COL-1), osteopontin (OPN), and Runt-related transcription factor 2 (RUNX2). We found that $\mathrm{TiO}_{2}$ nanotubes of different diameters $(30,70$, and $120 \mathrm{~nm})$ manufactured on Ti surface by anodisation had a well-defined structure. PDLCs grown on nanotube layers demonstrated polygonal morphology with more filopodia than those on flat Ti, which was especially evident on the nanotubes of larger diameters. However, cell adhesion and proliferation was the highest on the smallest $30 \mathrm{~nm}$ nanotubes. Similarly, mRNA levels of the ALP, COL-1, OPN, and RUNX2 genes increased in PDLCs cultured on $30 \mathrm{~nm} \mathrm{T_{2 }}$ nanotube layers compared to those in the cells grown on $70 \mathrm{~nm}$ and $120 \mathrm{~nm}$ nanotubes. In conclusion, small diameter $(30 \mathrm{~nm})$ nanotube layers can support PDLC adhesion, proliferation, and differentiation better than larger sized nanotubes, and consequently, have higher potential to promote bone formation and integration of an immediate implant.
\end{abstract}

Keywords: $\mathrm{TiO}_{2}$ nanotubes; Periodontal ligament cells; Adhesion; Proliferation; Osteogenic differentiation

\section{Introduction}

Dental implants, which represent artificial tooth roots to support a dental prosthesis have been successfully used as a popular approach to dental restoration [1]. Immediate implantation into fresh extraction sockets is an attractive alternative to delayed implant placement after alveolar healing because it presents several advantages such as reduction in rehabilitation time and number of surgical episodes, preservation of bone tissues, and improvement of the peri-implant gingival tissue aesthetics [2]. However, the difficulty in achieving primary stability leads to the early mobility of the implants thus limiting the reliability of this approach and its further application [3].

Søballe et al. have shown that micromovements $(150 \mu \mathrm{m})$ of dental implants induce interposition and subsequent immobilisation of fibrous tissue leading to the formation of new bone tissue [4,5]; similar results were obtained in dogs and monkeys [6,7]. Immediate implantation, which is the placement of the implant in the periodontium before the healing of the tooth extraction site, is followed by the formation of connective tissue by residual periodontal ligament cells (PDLCs) in the fresh extraction socket. It is known that PDLCs have the ability for multipotent differentiation and could form collagen fibers, cementum, and bone $[8,9]$. These cells are also involved in the complex process of osseointegration, i.e., establishment of a direct bone-to-implant anchorage without intervening connective tissue, which is essential for the success of immediate implantation [10].

To avoid the interference of connective tissues, two main factors should be considered: the surface of the implant fixture, which should promote osteogenic differentiation, and faster healing process. Compared with other metals used for implantation, titanium (Ti) and its alloys have attracted attention because of their higher biocompatibility, corrosion resistance, and mechanical properties. In the past decades, many strategies have been used to improve the durability and function of Ti-based dental implants [11].

Recently, the modification of implant surface topography at the nanoscale level has becomes one of the major research strategies to promote wound healing, new osteoblast differentiation, and subsequent implant integration [12]. $\mathrm{TiO}_{2}$ nanotube layers obtained by anodisation have received considerable attention as implant biomaterials $[13,14]$ because they could increase surface area and roughness, and improve nanoporous architecture and scaffold configuration of the implants though changes in the chemical composition and crystal structure [15-17]. As a result, $\mathrm{TiO}_{2}$ nanotubes grown on Ti surface enhance osteoblast adhesion, proliferation, gene expression [13,18] and improve osseointegration compared to flat $\mathrm{Ti}$ [19]. It has also been shown that the diameter of $\mathrm{TiO}_{2}$ nanotubes can significantly influence the behaviour of preosteoblasts and osteoblasts [20-22].

A number of studies have investigated the growth of osteoblast cell lines on $\mathrm{TiO}_{2}$ nanotube layers; however, there are few reports on PDLCs, which are important for the outcome of immediate implantation. This is the first investigation of PDLCs grown on $\mathrm{TiO}_{2}$ nanotubes of different diameters. Here, we evaluated cell morphology, actin cytoskeleton, adhesion, proliferation, and gene expression of PDLCs cultured on $\mathrm{TiO}_{2}$ nanotube layers formed on Ti substrate. The findings of this study can provide the parameters for further optimisation of implant design. 


\section{Materials and Methods}

\section{Fabrication of $\mathrm{TiO}_{2}$ nanotube layers}

$\mathrm{TiO}_{2}$ nanotubes were prepared by anodisation technique described earlier [22,23]. Ti thin foil $(0.25 \mathrm{~mm}$ thick $)$ with the purity of $99.5 \%$ (Alfa Aesar) was soaked in a mixture of $2 \mathrm{ml} 48 \% \mathrm{HF}, 3 \mathrm{ml} 70 \% \mathrm{HNO}_{3}$, and $100 \mathrm{ml}$ deionised water for $5 \mathrm{~min}$ to remove the naturally formed $\mathrm{TiO}_{2}$ layer, then washed with deionised water, and dried by nitrogen flow. $\mathrm{TiO} 2$ nanotubes of $30 \mathrm{~nm}, 70 \mathrm{~nm}, 120 \mathrm{~nm}$ in diameter were formed on the anodised Ti surfaces using the voltages of $5 \mathrm{~V}, 15 \mathrm{~V}, 25$ $\mathrm{V}$, respectively, in the electrolyte containing $1 \mathrm{M} \mathrm{H}_{3} \mathrm{PO}_{4}$ and $0.5 \mathrm{wt} \%$ HF for $3 \mathrm{~h}$; platinum was used as a counter electrode. After anodisation, the samples were washed with deionised water, dried by nitrogen flow, and the nanotubes were then sintered at $450^{\circ} \mathrm{C}$ for $3 \mathrm{~h}$. The experimental samples of $1 \mathrm{~cm} \times 1 \mathrm{~cm}$ were sterilised in a steam autoclave at $120^{\circ} \mathrm{C}$ for $30 \mathrm{~min}$.

\section{Substrate surface characterisation}

All samples were sputter-coated with gold using a Hummer I Sputter-coater for $3 \mathrm{~min}$, and surface microstructure of $\mathrm{TiO}_{2}$ nanotube layers was then examined by scanning electron microscopy (SEM; FEI Sirion 200, Hillsboro). The images were acquired at the magnification of $1,000 \times$ or $100,000 \times$.

\section{Isolation and culture of human PDLCs}

Human PDLCs were isolated from adult healthy premolars extracted for orthodontic reasons, and their use in this study was approved by the Institutional Review Board after obtaining patients' informed consent. Teeth were washed with phosphate-buffered saline (PBS), and periodontal ligament tissue was obtained from the middle third of the tooth root and cultured in Dulbecco's modified Eagle's medium (DMEM; Gibco, Grand Island, NY, USA) containing 10\% fetal bovine serum (FBS, Gibco), $100 \mathrm{U} / \mathrm{ml}$ penicillin and $100 \mathrm{mg} / \mathrm{l}$ streptomycin [24]. The cells were grown to confluence at $37^{\circ} \mathrm{C}$ in a $5 \%$ $\mathrm{CO} 2$ humidified incubator.

PDLCs were seeded on flat $\mathrm{Ti}$ and $\mathrm{TiO}_{2}$ nanotubes of $30 \mathrm{~nm}, 70 \mathrm{~nm}$, and $120 \mathrm{~nm}$ in diameter at the density of $2 \times 10^{4}$ cells $/ \mathrm{ml}$ for the attachment and proliferation assays, and at a higher density of $4 \times 10^{4}$ cells $/ \mathrm{ml}$ for the osteogenic differentiation assay; in the latter case, the cells were cultured in osteogenic medium $(50 \mu \mathrm{g} / \mathrm{ml}$ ascorbic acid, 10 $\mathrm{mM} \beta$-glycerophosphate, and $10 \mathrm{nM}$ dexamethasone).

\section{Cell morphology}

PDLCs of the third passage were seeded on the sample surface for $24 \mathrm{~h}$, washed twice with PBS, fixed in $2.5 \%$ glutaradehyde in PBS for 1 $\mathrm{h}$, and washed three times with PBS for $10 \mathrm{~min}$. Then, the samples were dehydrated in a graded series of alcohol $(35,50,75,90$, and $100 \%)$ for 10 min and dried by supercritical fluid CO2. Sample surfaces were sputter-coated in gold, and cell morphology was examined by the field emission SEM; each group $(\mathrm{n}=3)$ was evaluated at five spots: top, bottom, right, left, and middle.

\section{Actin staining}

After $24 \mathrm{~h}$ of culture, PDLCs were washed three times with PBS, fixed in $4 \%$ paraformaldehyde for $30 \mathrm{~min}$, and washed again with PBS.
The cells were then permeabilised with $0.1 \%$ Triton X-100 in PBS for 5 min, gently washed with PBS, incubated with $1 \%$ BSA for $20 \mathrm{~min}$ to block non-specific binding sites, and actin filaments were stained with phalloidin-TRITC $(20 \mu \mathrm{g} / \mathrm{ml}$; Sigma) for $30 \mathrm{~min}$. After washing with PBS, the cells were counter-stained with DAPI (Sigma) to visualise the nuclei, washed with PBS, and placed on glass slides using Fluoromount (Sigma). Actin formation was examined by confocal laser scanning microscopy (CLSM) using a TLS SP2 instrument (Leica, Wetzlar, Germany); the images were acquired with the red (actin) and blue (DAPI) filters.

\section{Cell adhesion}

To evaluate cell adhesion, PDLCs were seeded on the substrates for $2 \mathrm{~h}$, washed with PBS, and fixed in $4 \%$ paraformaldehyde for $15 \mathrm{~min}$; cell nuclei were labelled by DAPI for $5 \mathrm{~min}$. The images were obtained by CLSM, and adhered cells were counted using the Image-Pro 5.0 software (Media Cybernetic; Silver Springs, MD, USA).

\section{MTT assay}

Cell viability was evaluated 2, 4, and 7 days after PDLC seeding on the substrates using the MTT assay. The samples were washed in PBS and transferred to a new 24-well polystyrene culture plate; $20 \mu \mathrm{l}$ of 5 $\mathrm{mg} / \mathrm{ml}$ MTT (Sigma) in $200 \mu \mathrm{l}$ culture medium was added into each well. After $4 \mathrm{~h}$ of incubation at $37^{\circ} \mathrm{C}$, the medium was removed and $200 \mu \mathrm{l}$ DMSO was added to each well and mixed for $10 \mathrm{~min}$. DMSO extracts were transferred into a new 96-well polystyrene plate, and the absorbance of each solution was measured at the wavelength of 590 $\mathrm{nm}$ using a spectrophotometer (Safire $2^{\mathrm{rx}}$, Tecan, Männedorf, Switzerland).

\section{Gene expression analysis}

Gene expression in PDLCs grown on flat $\mathrm{Ti}$ and $\mathrm{TiO}_{2}$ nanotubes of different diameters was evaluated by real-time quantitative polymerase chain reaction (RT-qPCR). Total RNA was extracted from PDLCs cultured for 7 and 14 days using Trizol (Sigma), and $1 \mu$ g RNA was reverse transcribed using the Reverse Transcription Kit (TaKaRa, Japan) at $37^{\circ} \mathrm{C}$ for $15 \mathrm{~min}$ followed by $85^{\circ} \mathrm{C}$ for $5 \mathrm{~s}$. RT-qPCR analysis of ALP, COL-1, OPN, and RUNX2 expression was performed using a real-time PCR system (Bio-Rad, Hercules, CA, USA) at the following cycling conditions: $95^{\circ} \mathrm{C}$ for $10 \mathrm{~min}$ followed by 40 cycles of $95^{\circ} \mathrm{C}$ for $30 \mathrm{~s}, 60^{\circ} \mathrm{C}$ for $1 \mathrm{~min}$, and $72^{\circ} \mathrm{C}$ for $1 \mathrm{~min}$; PCR specificity for each gene was determined by the dissociation curve analysis at $95^{\circ} \mathrm{C}$ for $15 \mathrm{~s}$, $60^{\circ} \mathrm{C}$ for $1 \mathrm{~min}$ and $95^{\circ} \mathrm{C}$ for $15 \mathrm{~s}$. The primer sequences are listed in Table 1.

The expression of the tested genes was normalised to glyceraldehyde 3-phosphate dehydrogenase (GAPDH) used as a house-keeping gene and compared to that of the cells grown on flat Ti using the $2-\Delta \Delta \mathrm{C}$ method [25].

\section{Statistical analysis}

All experiments were conducted in triplicate and statistical analysis was performed using the SPSS 11.5 software. One-way ANOVA followed by the Student-Newman-Keuls post hoc test were used to evaluate differences between the samples; p-value of less than 0.05 was considered statistically significant. 
Citation: $\mathrm{Xu} \mathrm{L}, \mathrm{Lv} \mathrm{K}, \mathrm{Yu}$ WQ (2016) Effect of $\mathrm{TiO}_{2}$ Nanotube Layers Thickness on Periodontal Ligament Cells. Dentistry 6: 369. doi: $10.4172 / 2161-1122.1000369$

Page 3 of 7

\begin{tabular}{|l|l|l|l|}
\hline Gene & Primers (F=forward; R=reverse) & Accession Numbers & Product Size (bp) \\
\hline OPN & $\begin{array}{l}\text { F: 5'CATGAGAATTGCAGTGTTTGCT3' } \\
\text { R: 5'CTTGCAAGGGTCTGTGGGG' }\end{array}$ & NM_000582.2 & 186 \\
\hline \multirow{2}{*}{ ALP } & $\begin{array}{l}\text { F: 5'TCAAACCGAGATACAAGCAC3' } \\
\text { R: 5'CCACCAGCAAGAAGAAGC3' }\end{array}$ & NM_000478.4 & 219 \\
\hline COL-1 & $\begin{array}{l}\text { F: 5'TCCAACGAGATCGAGATCC3' } \\
\text { R: 5'AAGCCGAATTCCTGGTCT3' }\end{array}$ & NM_000088.3 & 191 \\
\hline \multirow{2}{*}{ RUNX2 } & $\begin{array}{l}\text { F: 5'GCCTTCAAGGTGGTAGCCC3' } \\
\text { R: 5'CGTTACCCGCCATGACAGTA3' }\end{array}$ & NM_001015051.3 & 67 \\
\hline \multirow{2}{*}{ GAPDH } & $\begin{array}{l}\text { F: 5'TTGGACAGTCAGCCGCATCTT3' } \\
\text { R: 5'ATCCGTTGACTCCGACCTTCA3' }\end{array}$ & NM_002046.3 & 90 \\
\hline
\end{tabular}

Table 1: Primer sequence used for Real-time PCR.

\section{Results}

\section{Sample characterisation}

Surface microstructure of flat $\mathrm{Ti}$ and $\mathrm{TiO}_{2}$ nanotubes of different diameters was examined by SEM. The surface of flat Ti exhibited randomly positioned shallow grooves due to mechanical polishing (Figure 1a), whereas that of the nanotubes formed on the anodised Ti substrates had well-defined structurally ordered morphology (Figures 1b-1d).

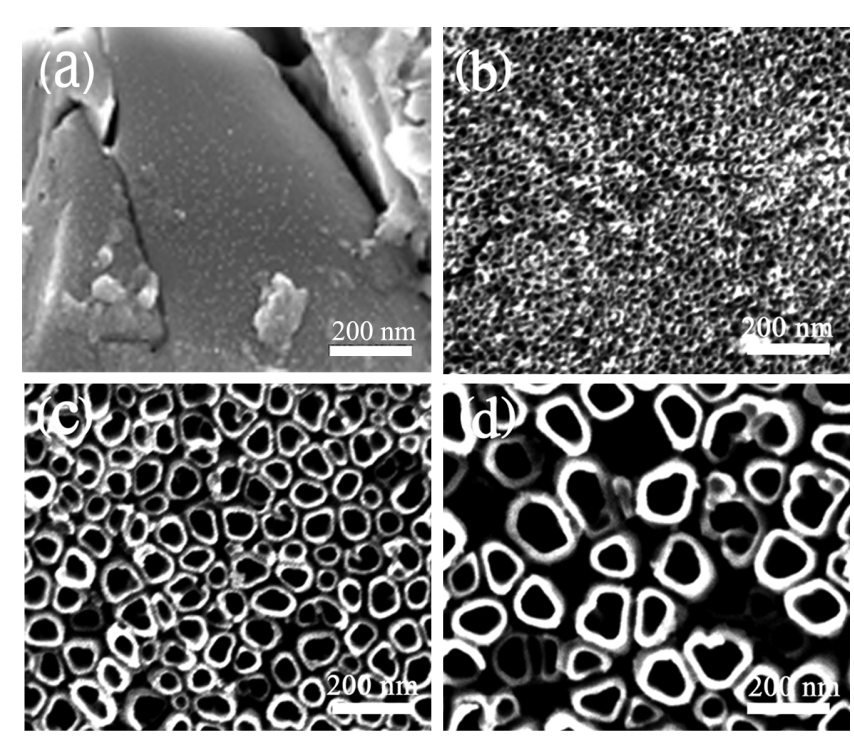

Figure 1: Physical characterization of different sized nanotube surfaces. The images show (a) flat Ti and highly ordered nanotubes with three different diameters (b) $30 \mathrm{~nm}$, (c) $70 \mathrm{~nm}$, and (d) 120 nm.

We randomly selected 30 nanotubes in each group and calculated their diameter using the Image-Pro 5.0 software. The diameter of nanotube layers anodised at $5 \mathrm{~V}, 15 \mathrm{~V}$, and $25 \mathrm{~V}$ was $30.33 \pm 4.35 \mathrm{~nm}$, $74.53 \pm 9.28 \mathrm{~nm}$, and $124.25 \pm 17.98 \mathrm{~nm}$, the thickness was $\sim 100,300$, and $500 \mathrm{~nm}$, and surface roughness was $9.29 \pm 0.68,18.02 \pm 0.98$, and $45.56 \pm 1.20 \mathrm{~nm}$ respectively (for flat Ti, surface roughness measured in our previous study was $4.63 \pm 0.39$ ) [23].

\section{PDLC morphology}

Morphological analysis of PDLCs grown on differently sized $\mathrm{TiO}_{2}$ nanotubes for $24 \mathrm{~h}$ was performed by SEM (Figure 2). The cells cultured on flat Ti exhibited elongated shape (Figure 2a), whereas those grown on $30 \mathrm{~nm}$ nanotube surface were spread freely and developed extensive filipodia (Figure 2b), which facilitated cell anchorage to the nanotubular structures potentially stimulating PDLC differentiation. The cells cultured on $70 \mathrm{~nm}$ (Figure 2c) and $120 \mathrm{~nm}$ (Figure 2d) nanotube layers displayed polygonal shape with minimal spreading and increased number of filopodia compared to PDLCs grown on flat Ti or $30 \mathrm{~nm}$ nanotube layers.
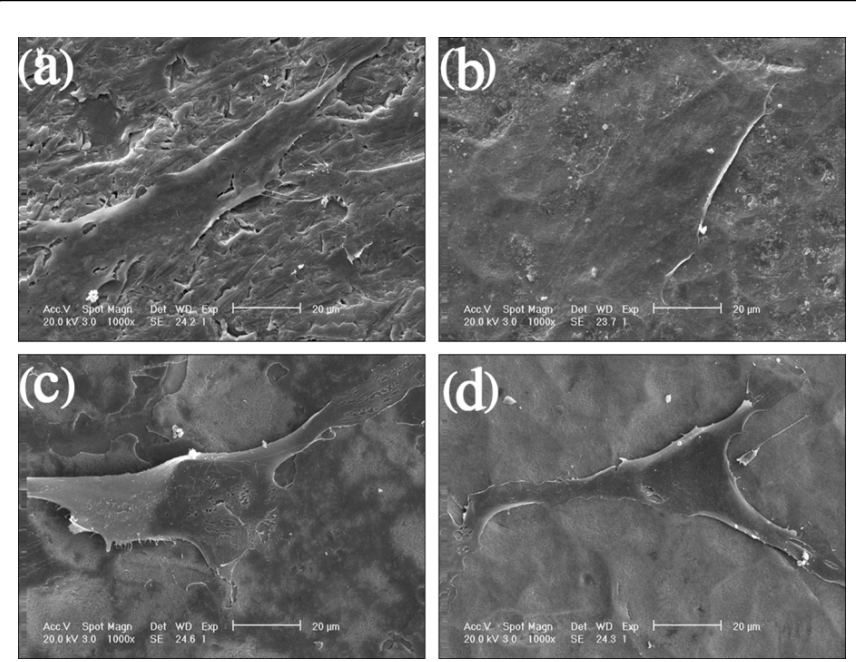

Figure 2: SEM micrographs of PDLCs seeded on (a) flat Ti; (b) 30 $\mathrm{nm}$ nanotube layers; (c) $70 \mathrm{~nm}$ nanotube layers; and (d) $120 \mathrm{~nm}$ nanotube layers after $24 \mathrm{~h}$. The PDLCs on the nanotube layers were displayed polygon shape with more filopodias than flat $\mathrm{Ti}$, especially on the $70 \mathrm{~nm}$ and $120 \mathrm{~nm}$ nanotube layers. 
Citation: $\mathrm{Xu} \mathrm{L}, \mathrm{Lv} \mathrm{K}, \mathrm{Yu}$ WQ (2016) Effect of $\mathrm{TiO}_{2}$ Nanotube Layers Thickness on Periodontal Ligament Cells. Dentistry 6: 369. doi:

Page 4 of 7

The analysis of PDLC actin cytoskeleton by immunofluorescence revealed similar morphological trends observed by SEM, i.e., polygonal shape and increased extension of filopodia for the cells cultured on nanotubes of larger diameter (Figure 3). In addition, actin fibers in PDLCs cultured on flat $\mathrm{Ti}$ and $30 \mathrm{~nm}$ nanotubes looked longer and directionally organised compared to those in the cells grown on $70 \mathrm{~nm}$ and $120 \mathrm{~nm}$ nanotubes.
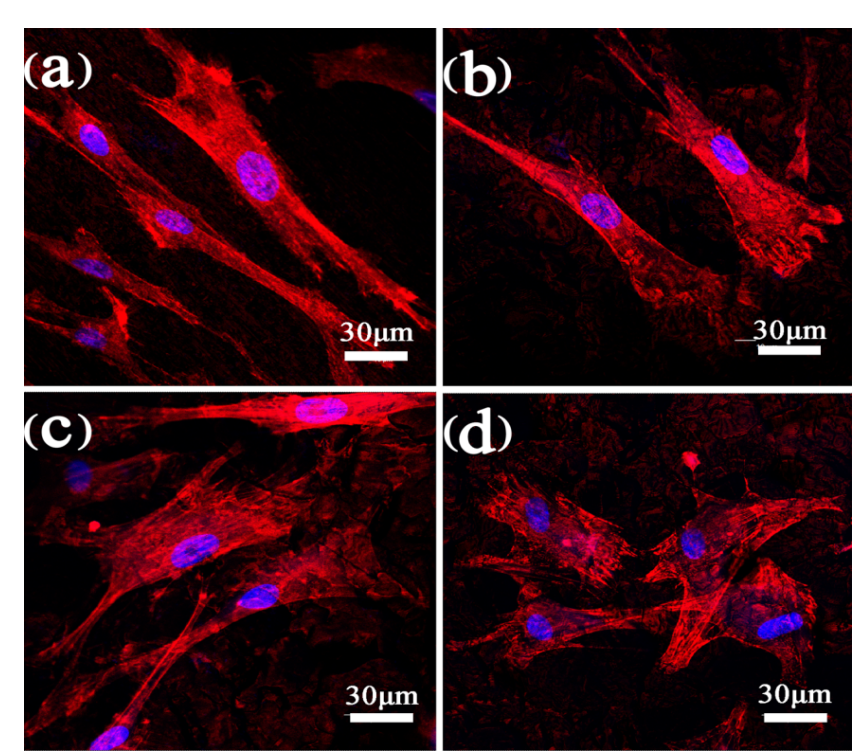

Figure 3: Phalloidin staining of the actin cytoskeleton of adherent PDLCs after $24 \mathrm{~h}$ of incubation on the different samples: (a) flat Ti; (b) $30 \mathrm{~nm}$ nanotube layers; (c) $70 \mathrm{~nm}$ nanotube layers; and (d) 120 nm nanotube layers.

\section{Cell adhesion}

Figure 4 shows PDLC adhesion to nanotubes of different diameters after $2 \mathrm{~h}$. Cell adhesion to $30 \mathrm{~nm}$ nanotubes was the highest compared to other tested surfaces. The number of PDLCs attached to $30 \mathrm{~nm}$ nanotubes significantly exceeded that detected on flat $\mathrm{Ti}(\mathrm{p}<0.05)$, as well as on $70 \mathrm{~nm}$ and $120 \mathrm{~nm}$ nanotube surfaces $(\mathrm{p}<0.01)$.

\section{Cell proliferation}

The analysis of PDLC proliferation on different substrates indicated that on day 2, cell multiplication did not significantly vary between the groups (Figure 5). On day 4, however, cell proliferation rate on $30 \mathrm{~nm}$ and $70 \mathrm{~nm}$ nanotubes was statistically higher than that on flat Ti and $120 \mathrm{~nm}$ nanotubes $(\mathrm{p}<0.05)$, and on day 7 , it was significantly higher for the $30 \mathrm{~nm}$ group than for other cells $(\mathrm{p}<0.01)$. In addition, PDLCs grew significantly slower on $120 \mathrm{~nm}$ nanotubes than on other tested surfaces $(\mathrm{p}<0.01$ for day 7 ) (Figure 5 ).

\section{Gene expression analysis}

The expression of ALP, COL-1, OPN, and RUNX2 in PDLCs grown on different Ti surfaces was analysed on days 7 and 14 of culture by qPCR (Figure 6). At day 7, the ALP gene associated with early osteogenic differentiation and the COL-1 gene encoding a matrix protein synthesised by osteoblasts, showed higher expression in the cells cultured on $30 \mathrm{~nm}$ nanotubes compared to other groups $(\mathrm{p}<0.05$; Figures $6 \mathrm{a}$ and $6 \mathrm{~b}$ ). The OPN gene coding for the most abundant noncollagenous matrix protein in the bone and associated with bone mineral metabolism, was upregulated in PDLCs grown on $30 \mathrm{~nm}$ nanotubes at day 7 and especially at day 14, when its expression increased 2.5 fold $(\mathrm{p}<0.01$; Figure $6 \mathrm{c})$. The RUNX2 gene, which is essential for osteoblastic differentiation, showed a similarly tendency in PDLCs grown on $30 \mathrm{~nm}$ nanotubes ( $\mathrm{p}<0.05$; Figure $6 \mathrm{~d}$ ).
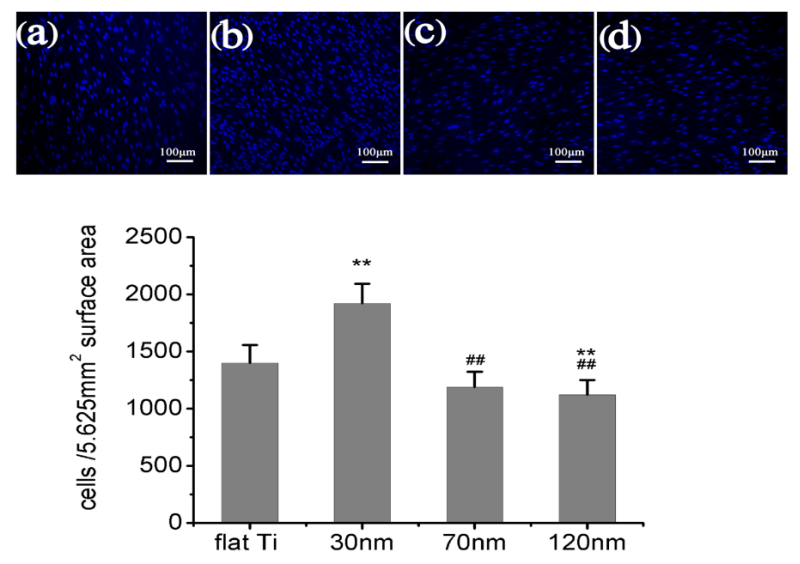

Figure 4: Comparative study of the adhesion of PDLCs on (a) flat Ti; (b) $30 \mathrm{~nm}$ nanotube layers; (c) $70 \mathrm{~nm}$ nanotube layers; and (d) 120 $\mathrm{nm}$ nanotube layers. The bar graphs show the average \pm standard error bars. ${ }^{*} \mathrm{p}<0.01$ compared to flat $\mathrm{Ti}, \# \# \mathrm{p}<0.01$ compared to 30 $\mathrm{nm}$ nanotube layers.

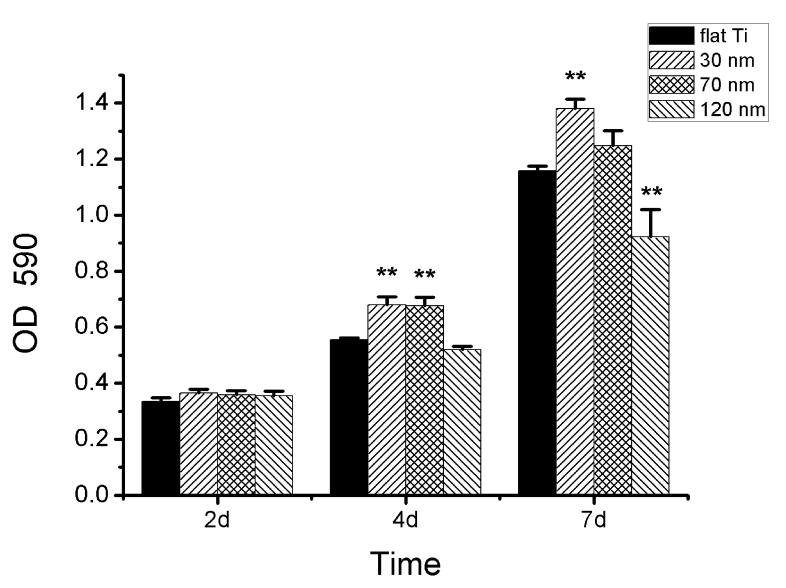

Figure 5: MTT assay data showing the proliferation of PDLCs on flat $\mathrm{Ti}$ and $\mathrm{TiO}_{2}$ nanotubes. The error bars in the figure represent the standard deviation for three samples for each data. ${ }^{*} \mathrm{p}<0.05$ compared to flat $\mathrm{Ti},{ }^{* *} \mathrm{p}<0.01$ compared to flat $\mathrm{Ti}$. 

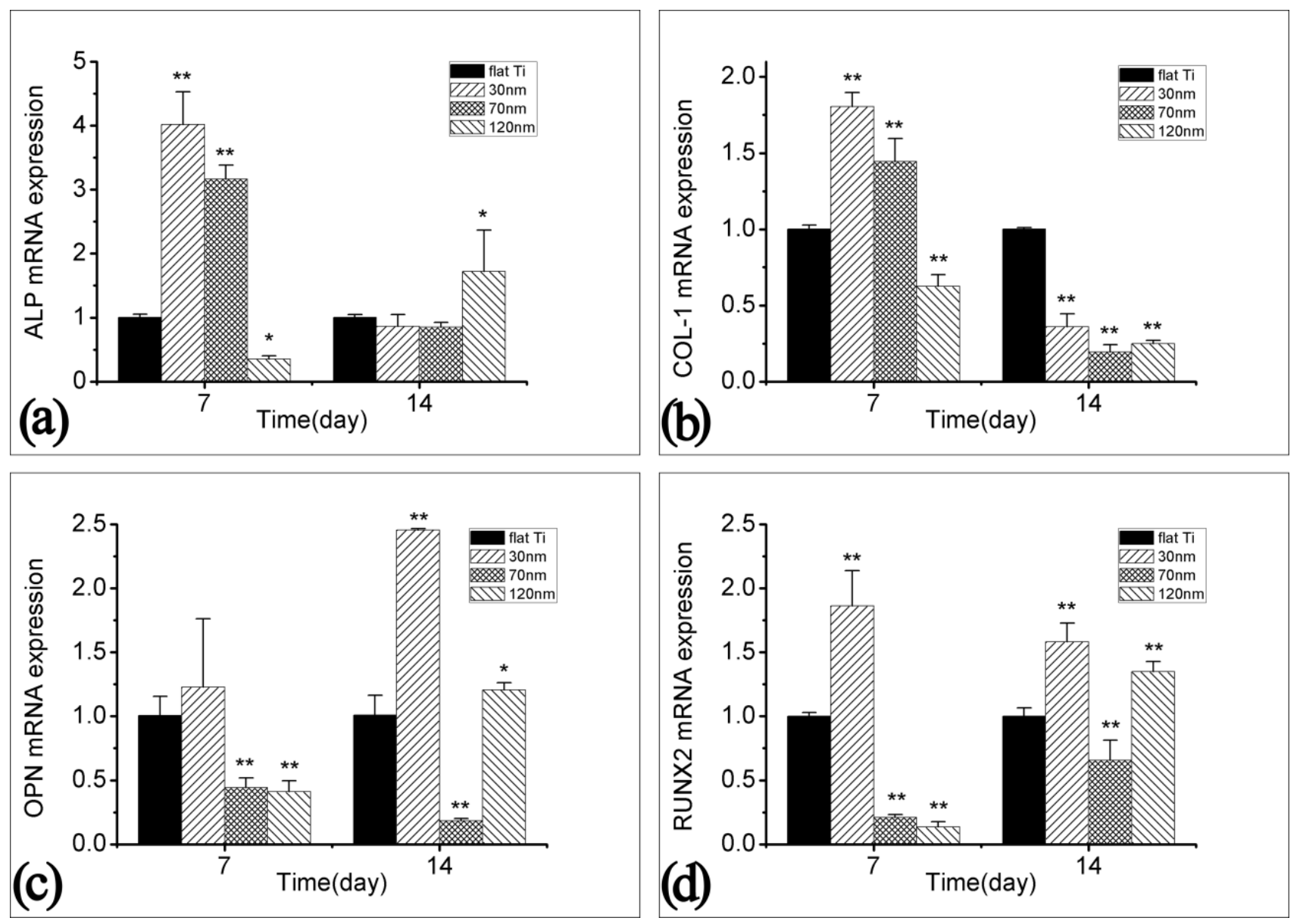

Figure 6: The genes (a) ALP, (b) COL-1, (c) OPN, and (d) RUNX2 were assayed by Real-time PCR at days 7 and 14, after PDLCs seeding on different samples. The results were normalized by GAPDH and shown as fold change (baseline $=$ day 7 cells on flat Ti; ${ }^{\star} \mathrm{p}<0.05$ compared to flat $\mathrm{Ti},{ }^{* *} \mathrm{p}<0.01$ compared to flat $\left.\mathrm{Ti}\right)$.

\section{Discussion}

The ability of PDLCs for osteogenic differentiation has been demonstrated in many previous studies $[25,26]$. The improvement of PDLC adhesion to and proliferation on implant surfaces could facilitate osseointegration and healing leading to the success of immediate implantation. In this study, we evaluated the effects of differently sized $\mathrm{TiO}_{2}$ nanotube layers on PDLC adhesion, proliferation, and expression of the genes involved in osteoblastic differentiation. Our findings demonstrate that the diameter of nanotubes could influence the behaviour and metabolic activity of PDLCs.

Cell adhesion and surface spreading influences such cellular functions as proliferation, migration, and extracellular matrix production [26]. Therefore, we evaluated PDLC attachment to the surface of $\mathrm{TiO}_{2}$ nanotubes with different diameter by SEM. Our observation that cell adhesion to $30 \mathrm{~nm}$ nanotubes was the highest among the tested surfaces is consistent with the results obtained for other cell types $[14,15]$. The enhanced adhesion may be related to the increased adsorption from the culture medium of serum proteins such as fibronectin and vitronection, which play an important role in cell adhesion [21]. Brammer et al. have reported that small-diameter (30 nm) $\mathrm{TiO}_{2}$ nanotubes provide the highest cell adhesion rate because of the increased surface for protein adsorption, whereas on large diameter nanotubes, proteins were rarely adsorbed on the upper wall surface because of large empty pores [20].

The proliferation of PDLCs cultured on $30 \mathrm{~nm}$ nanotubes was higher than that on $70 \mathrm{~nm}$ and $120 \mathrm{~nm}$ nanotubes, which was consistent with a previous study reporting that the adhesion, proliferation, migration, and differentiation of mesenchymal stem cells and osteoblast-like cells were maximal on $15 \mathrm{~nm}$ nanotubes and minimal on $100 \mathrm{~nm}$ nanotubes [27]. The cells seeded on the surface of small diameter $\mathrm{TiO}_{2}$ nanotubes showed higher formation of focal contacts and actin stress fibers, as well as upregulation of paxillin phosphorylation compared to those grown on $\mathrm{TiO}_{2}$ nanotubes of larger sizes [28]. However, different results were obtained for mouse calvarial MC3T3-E1 cells and bone marrow stromal cells (BMSCs), indicating that the response may be cell type-specific [22,23].

The effect of nanotube layers on promoting osteogenic differentiation of PDLCs was a major focus of this study. Quantitative PCR analysis of osteogenic differentiation markers ALP, COL-1, OPN, and RUNX2 showed that the expression of these genes was increased in PDLCs grown on $30 \mathrm{~nm}$ nanotubes, which was in contrast to gene 
expression in osteoblast-like cells reported previously [20,23]. These studies have shown that MC3T3-E1, osteoblasts, and BMSCs demonstrated much higher expression of osteogenic genes when grown on larger size $\mathrm{TiO}_{2}$ nanotubes, which contributed to cell cytoskeletal tension and formation of stress fibers resulting from a dramatic stem cell elongation. Such conflicting results can probably arise from the differences in cell type and origin.

PDLCs are useful cells for the reconstruction of periodontal tissues because they contain osteogenic and fibrogenic progenitor cells $[29,30]$, which differentiate into fibroblasts, cementoblasts, or osteoblasts depending on the surrounding conditions. A recent study on stem cells derived from the periodontal ligament has reported increased osteogenic differentiation of the cells seeded on rough surfaces coated with $\mathrm{Al}_{2} \mathrm{O}_{3}$ particle-treated $\mathrm{Ti}$ [31]. Furthermore, another study investigating MC3T3, human bone marrow stromal cells, murine femoral stromal cells, and canine bone marrow cells have reported significant variations in their mineralisation and proliferation response to $\mathrm{Ti}$ surfaces [32]. Overall, these results emphasise the existence of cell-specific differences in the osteogenic differentiation between osteoblast-like cells and PDLCs. However, the underlying mechanisms and the corresponding signalling pathway are unclear and require further investigation.

In the fresh socket after tooth extraction, the residual periodontal ligament tissue remained in the cervix and tooth root tip, and can critically influence immediate implantation. Therefore, to further optimise implant design, the interaction of PDLCs with the implant surface should be considered. Given that the osteogenic differentiation of PDLCs on $\mathrm{TiO}_{2}$ nanotubes is distinct from that of osteoblasts, it can be suggested that to achieve better osseointegration, different surface sections of the immediate implants can be covered with $\mathrm{TiO}_{2}$ nanotubes of various diameter. Further studies are needed to test this hypothesis.

\section{Conclusions}

In summary, our study demonstrates that PDLCs cultured on small diameter $(30 \mathrm{~nm}) \quad \mathrm{TiO}_{2}$ nanotubes showed higher adhesion and proliferation, as well as expression of osteogenic genes compared to those grown on flat $\mathrm{Ti}$ or large diameter (70 nm and $120 \mathrm{~nm}$ ) nanotubes. Our results indicate that PDLCs have a potential for bone formation on $\mathrm{TiO}_{2}$ nanotube surfaces and that their impact should be considered when manufacturing the materials to be used for immediate implantation.

\section{Acknowledgements}

This work was supported by Shanghai Leading Academic Discipline Project (Project Number: S30206) and Science and Technology committee of Shanghai (08DZ2271100) and Shanghai Leadind Academic Discipline Project (T0202), and National Youth Natural Science Foundation of China (81300912).

\section{References}

1. Van Steenberghe D (1989) A retrospective multicenter evaluation of the survival rate of osseointegrated fixtures supporting fixed partial prostheses in the treatment of partial edentulism. J Prosthet Dent 61: 217-223.

2. Boix D, Gauthier O, Guicheux J, Pilet P, Weiss P, et al. (2004) Alveolar bone regeneration for immediate implant placement using an injectable bone substitute: an experimental study in dogs. J Periodontol 75: 663-671.
3. Bhola M, Neely AL, Kolhatkar S (2008) Immediate implant placement: clinical decisions, advantages, and disadvantages. J Prosthodont 17: 576-581.

4. Søballe K, Brockstedt-Rasmussen H, Hansen ES, Bünger C (1992) Hydroxyapatite coating modifies implant membrane formation. Controlled micromotion studied in dogs. Acta Orthop Scand 63: 128-140.

5. Søballe K, Hansen ES, Brockstedt-Rasmussen H, Jørgensen PH, Bünger C (1992) Tissue ingrowth into titanium and hydroxyapatite-coated implants during stable and unstable mechanical conditions. J Orthop Res 10: 285-299.

6. Brunski JB, Moccia AF, Pollock SR, Korostoff E, Trachtenberg DI (1979) The influence of functional use of endosseous dental implants on the tissue-implant interface. I. Histological aspects. J Dent Res 58: 1953-1969.

7. Lum LB, Beirne OR, Curtis DA (1991) Histologic evaluation of hydroxylapatite-coated versus uncoated titanium blade implants in delayed and immediately loaded applications. Int J Oral Maxillofac Implants 6: 456-462.

8. Fujii S, Maeda H, Wada N, Tomokiyo A, Saito M, et al. (2008) Investigating a clonal human periodontal ligament progenitor/stem cell line in vitro and in vivo. J Cell Physiol 215: 743-749.

9. Itaya T, Kagami H, Okada K, Yamawaki A, Narita Y, et al. (2009) Characteristic changes of periodontal ligament-derived cells during passage. J Periodontal Res 44: 425-433.

10. Pivodova V, Frankova J, Ulrichova J (2011) Osteoblast and gingival fibroblast markers in dental implant studies. Biomed Pap Med Fac Univ Palacky Olomouc Czech Repub 155: 109-116.

11. Riedel NA, Williams JD, Popat KC (2011) Ion Beam Etching Titanium for Enhanced Osteoblast Response. J Mater Sci 46. 6087-6095.

12. Falaras P, Stergiopoulos T, Tsoukleris DS (2008) Enhanced efficiency in solid-state dye-sensitized solar cells based on fractal nanostructured $\mathrm{TiO} 2$ thin films. Small 4: 770-776.

13. Minagar S, Wang J, Berndt CC, Ivanova EP, Wen C (2013) Cell response of anodized nanotubes on titanium and titanium alloys. J Biomed Mater Res A 101: 2726-2739.

14. Pang X, Wang Y, Liu L (2009) Features of NanoTiO2 and Its Influences on Proliferation of Cell. Journal of Science Conference Proceedings 1: 177-180.

15. Popat KC, Leary Swan EE, Mukhatyar V, Chatvanichkul KI, Mor GK, et al. (2005) Biomaterials 26: 4516-4522.

16. Das K, Bose S, Bandyopadhyay A (2009) TiO2 nanotubes on Ti: Influence of nanoscale morphology on bone cell-materials interaction. J Biomed Mater Res A 90: 225-237.

17. Yao C, Slamovich EB, Webster TJ (2008) Enhanced osteoblast functions on anodized titanium with nanotube-like structures. J Biomed Mater Res A 85: 157-166.

18. Wu C, Ramaswamy Y, Liu X, Wang G, Zreiqat H (2009) Plasma-sprayed CaTiSiO5 ceramic coating on Ti-6Al-4V with excellent bonding strength, stability and cellular bioactivity. J R Soc Interface 6: 159-168.

19. Von Wilmowsky C, Bauer S, Lutz R, Meisel M, Neukam FW, et al. (2009) In vivo evaluation of anodic $\mathrm{TiO} 2$ nanotubes: an experimental study in the pig. J Biomed Mater Res B Appl Biomater 89: 165-171.

20. Brammer KS, Oh S, Cobb CJ, Bjursten LM, Van der Heyde H, et al. (2009) Improved bone-forming functionality on diameter-controlled $\mathrm{TiO}(2)$ nanotube surface. Acta Biomater 5: 3215-3223.

21. Oh S, Brammer KS, Li YS, Teng D, Engler AJ, et al. (2009) Stem cell fate dictated solely by altered nanotube dimension. Proc Natl Acad Sci USA 106: 2130-2135.

22. Gongadze E, Kabaso D, Bauer S, Park J, Schmuki P, et al. (2013) Adhesion of osteoblasts to a vertically aligned $\mathrm{TiO} 2$ nanotube surface. Mini Rev Med Chem 13: 194-200.

23. Yu WQ, Jiang XQ, Zhang FQ, Xu L (2010) The effect of anatase TiO2 nanotube layers on MC3T3-E1 preosteoblast adhesion, proliferation, and differentiation. J Biomed Mater Res A 94: 1012-1022. 
Citation: $\quad \mathrm{Xu} \mathrm{L}, \mathrm{Lv} \mathrm{K}, \mathrm{Yu}$ WQ (2016) Effect of $\mathrm{TiO}_{2}$ Nanotube Layers Thickness on Periodontal Ligament Cells. Dentistry 6: 369. doi: $10.4172 / 2161-1122.1000369$

Page 7 of 7

24. Oates TW, Rouse CA, Cochran DL (1993) Mitogenic effects of growth factors on human periodontal ligament cells in vitro. J Periodontol 64: 142-148.

25. Analysis of relative gene expression data using real-time quantitative PCR and the 2(-Delta Delta C(T)) Methods 25: 402-408.

26. Eisenbarth E, Velten D, Breme (2007) Biomimetic implant coatings. Biomol Eng 24: 27-32.

27. Park J, Bauer S, Schlegel KA, Neukam FW, Von der Mark K, et al. (2009) TiO2 nanotube surfaces: $15 \mathrm{~nm}$-an optimal length scale of surface topography for cell adhesion and differentiation. Small 5: 666-671.

28. Park J, Bauer S, Von der Mark K, Schmuki P (2007) Nanosize and vitality: $\mathrm{TiO} 2$ nanotube diameter directs cell fate. Nano Lett 7: 1686-1691.
29. Kim SE, Yun YP, Han YK, Lee DW, Ohe JY, et al. (2014) Osteogenesis induction of periodontal ligament cells onto bone morphogenic protein-2 immobilized PCL fibers. Carbohydr Polym 99: 700-709.

30. Bartold PM, McCulloch CA, Narayanan AS, Pitaru S (2000) Tissue engineering: a new paradigm for periodontal regeneration based on molecular and cell biology. Periodontol 24: 253-269.

31. Heo YY, Um S, Kim SK, Park JM, Seo BM (2010) Responses of periodontal ligament stem cells on various titanium surfaces. Oral Dis 17: 320-327.

32. Hacking SA, Harvey E, Roughley P, Tanzer M, Bobyn J (2008) The response of mineralizing culture systems to microtextured and polished titanium surfaces. J Orthop Res 26: 1347-1354. 